\title{
Work-Life Balance, Employee Job Performance and Satisfaction Among Doctors and Nurses in Malaysia
}

\author{
Oscar Dousin \\ Faculty of Business, Economics and Accountancy, Universiti Malaysia Sabah \\ UMS Rd., 88400, Kota Kinabalu, Sabah, Malaysia \\ E-mail: odousin@ums.edu.my
}

Ngan Collins

School of Management, College of Business, RMIT University

Bld. 80, 445 Swanston St., Melbourne 3000, Australia

E-mail: ngan.collins@rmit.edu.au

\author{
Balvinder Kaur Kler \\ Faculty of Business, Economics and Accountancy, Universiti Malaysia Sabah \\ UMS Road, 88400, Kota Kinabalu, Sabah, Malaysia \\ E-mail: balvinder@ums.edu.my
}

Received: Oct. 24, 2019 Accepted: Nov. 19, 2019 Online published: Nov. 21, 2019

doi:10.5296/ijhrs.v9i4.15697 URL: https://doi.org/10.5296/ijhrs.v9i4.15697

\begin{abstract}
In this era, the concepts of human resource management (HRM) practices have evolved to the implementation of work-life balance (WLB) practices, such as: flexible working hours and supportive supervision. WLB practices have shown a great influence on employee attraction, retention, motivation and development. This study examines the relationship between WLB practices on employee job performance as well as the mediating effect of job satisfaction in the relationship between work-life balance practices and employee job performance among doctors and nurses in East Malaysia. The study surveys 491 doctors and nurses in the East Malaysia states of Sabah and Sarawak in 2016-2017. Four hypotheses were tested with validated measures of WLB practices (flexible working hours and supportive supervision),
\end{abstract}


job satisfaction and job performance. Findings revealed that flexible working hours and supportive supervision has a significant and positive impact to job performance. Job satisfaction positively mediates the relationship between flexible working hours and supportive supervision towards job performance. An effective WLB practices will improve employees' job satisfaction which eventually increase their job performance and productivity. This study's findings aim to assist the Malaysian healthcare industry in improving doctors' and nurses' attraction, retention and motivation.

Keywords: work-life balance, job performance, job satisfaction, medical doctors, nurses, Malaysia

\section{Introduction}

In recent years, the concept of WLB has become a critical issue in HRM literature. It emphasises on the effective management of individual professional work, family responsibilities and other personal activities (Keelan, 2015). Furthermore, with a shift in globalisation, the role of work to individuals have changed simultaneously too (Joshi et al., 2002). Even though work is still being perceived as essential, but it also a critical factor to improve personal satisfaction. Therefore, one of the motivating factors that help the accomplishment of personal and professional goals is the introduction of work-life benefits and programs in organisations (Joshi et al., 2002).

In the context of the Malaysian economic development strategy, the healthcare industry has been identified as one of the nation's key economic contributors in the 12 National Key Economic Area (NKEAs) in the nation's Economic Transformation Programme (Jabatan Perdana Menteri, 2012). There is a development of the industry to promote medical tourism and it has been recognised as one of the best in the South-East Asia region (Allianz, 2013).

In the contrast of its important role in the nation's economy, Malaysian healthcare industry still has suffered with a lack of manpower as measured by the World Health Organisation (WHO). For example, in 2015, the ratio of doctor per population in Sarawak was 1:1104, whereas in Sabah for 2018 was 1:1200. This figure is still far below the WHO standard for Malaysia, which is 1:600. The shortage of personnel has gotten even more critical for the nursing professions because a large wave of migration movement among nursing professionals leaving the country for overseas postings (BERNAMA, 2008; myMetro, 2014; Yazid, 2010; Augustin, 2017).

The healthcare professionals have been known for their exhaustive nature of work. In general, this profession is demanded to work in extended hours with high stress and less work flexibility, which eventually has a significant impact on their work-life balance, job performance and well-being. This manpower shortage in Malaysian healthcare industry has pushed this situation even further because it forces healthcare professionals to work in long hours with high stress and less flexibility, which has a significant impact on their job performance and satisfaction. Understanding the criticality of work-life balance therefore is important because it contributes to improve human resource policies and WLB practices in the Malaysian healthcare industry. This paper aims to address the above issue by 
investigating to what extend is the relationship between WLB practices and employee job performance. It also investigates how the mediating effect of job satisfaction in the relationship between work-life balance practices and employee job performance. To do so, in section 2, we undertake a literature review of the key related theories including work life balance, job satisfaction and job performance to learn how those elements relate to each other in the workplace context. These reviews will act as a foundation for us to develop the study's hypothesises that will describe in section 3. The quantitative approach and the study's result's analysis will detail in section 4 and 5 . The final section will present the key findings and discussions as well as the key contributions of this paper.

\section{Literature Review}

\subsection{Work-Life Balance Practices}

Work-life balance is a completion of role-related expectation that are negotiated and shared between individuals and their role-related partners in their work and families (Gryzwacz \& Carlson, 2007). It refers to the act of effectively managing a balance within individuals' three domains in life, including organisation, social and personal life (Poulose \& Sudarsan, 2014; Keelan, 2015). Several studies highlighted the main constructs of WLB practices and its outcomes. These researchers recommended that workplace policies and support in providing WLB plans will enhance employee well-being, organisational commitment and job satisfaction (Cegarra-Leiva et al., 2012; Greenhaus et al., 2003; Haar, 2013; Morganson et al., 2010; Noor, 2011). Workers may have the tendency to faced personal conflicts if they unable to balance the demand of their work and personal life. Moen et al. (2008) defined conflict as an interference of work and family roles which generates tensions for the individuals as a direct outcome of incompatible pressures from an individual's work and family role. Thus, organisations are encouraged to provide workplace policies that will enhance employee WLB which improves well-being and eventually boost organisational productivity and performance (Haar, 2013).

One of the earliest theories in studying WLB is the spillover effect theory (Westman, 2002; Googins, 1991). It refers to a person feelings, attitudes and behaviours of their work which will be influence by other domains such as their family, which will lead to a potential spillover between these two domains (Googins, 1991). A positive spillover could improve individuals' performance while a negative one could lead to an opposite effect (Pedersen et al., 2008). In relations to WLB practices, it can be observed through supportive supervisors or colleagues, which could alleviate work-family spillovers (Garcia Cabrera et al., 2018; Wu et al., 2012). In addition, employer-oriented flexible work schedule also will positively influence work to family spillover. Therefore, an employee oriented, flexible working practices and family-friendly can be an employees' active spillover from family to work in providing an adequate balance between work and family (Pedersen et al., 2008; Lott, 2018; Ruppanner \& Pixley, 2012).

There are several empirical studies on WLB among medical professionals in Malaysia. Sibbald et al. (2000) studied the advancement in the healthcare system from clinician-centred to patient-centred which resulted to a higher work-pressure among doctors as which increase 
their work-related stress and burnout. This issue is worsening in Malaysia due to the shortages of medical professionals, increasing number of patients which leads to a high-intensity of daily clinical routine, such as long working hours and working under time pressure (Cooper et al., 1989; Sibbald et al., 2000). Razak et al. (2011) further examined the issues of work overload, spousal support and job involvement in work-family conflict among doctors in Peninsular Malaysia. Their study suggested that work overload negatively affect work involvement with family and resulted in exhaustion and fatigue which eventually influence doctors' motivation. In a similar setting, Mohamed and Mohamad (2012) studied the issue of quality of work-life among nurses and recommended work-life balance strategy as well as a voluntary alternate scheduling which could possibly lessen work-life conflict. Rashid et al. (2011) further suggested that social support is vital to work-family enhancement which guarantees life satisfaction among nurses. This study was supported by Al-Dubai et al. (2013) who suggested that medical resident-supervisor relationships, work overload and environment could influence employee emotional burnout and motivation. Their study proposed an adequate mentoring, motivation and fair assessment could prevent negative well-being among medical residents in Malaysia.

These reviews proposed key elements such as flexible working hours and supervisory support to established employee WLB. While it is obvious that studies on WLB in relation to employee job performance and satisfaction is a common phenomenon among healthcare professions, at present, little studies have been conducted specifically in the East Malaysia healthcare sector.

\subsection{Job Satisfaction}

Job satisfaction is a significant concept in any organisations as it will influence employees job performance and morale (Maslach et al., 2001; Zapf et al., 2001). It refers to employees' feeling and response towards their job (Smucker et al., 2003). In an organisational context, it is basically an employee overall attitude and approach towards their salary, working conditions and control, job promotions, social relationships in the workplace, recognitions as well as group relations apart from their work life (Blum \& Naylor, 1968). Employees' job satisfaction could be measured by their attitudes, job performance, turnover rates, absenteeism, grievances and unpunctuality (Wagner, 1994).

\subsection{Job Performance}

Employee job performance is a work behaviour which discusses to the means employee behave in responding to some unsettled work-life conflicts, conditions or circumstances in their workplace (Pitt-Catsouphes et al., 2007). It is also defined as the level of individuals' productivity relative to their co-workers on numerous job-related behaviours and outcomes (Babin \& Boles, 1998). Previous studies suggested that work-life conflict has a negative effect on employees' job performance (Frone \& Russell, 1997; Netemeyer et al., 2004). Therefore, to improve employee job performance, a balance between work and life should be achieved (Madsen, 2006). 


\section{The Development of Research Hypotheses and Conceptual Framework}

In recent years, researches on WLB have been conducted in an organisational context due to importance for both organisation and employees. From an employee perspective, WLB will improve their job satisfaction, organisational commitment, well-being and performance by reducing work-family conflicts (Allen et al., 2000; Kossek \& Ozeki, 1998). Thus, workplace policies and practices in providing WLB programs is essential (Cegarra-Leiva et al., 2012; Greenhaus et al., 2003; Haar, 2013; Morganson et al., 2010; Noor, 2011; Wagner, 1994). These suggestions have been supported by various researchers which suggested that organisations should developed HR policies that promotes flexible working hours to enhance employees WLB (Hacker \& Doolen, 2003; Hyman \& Summers, 2004). For organisations, a sound WLB policies will have a significant influence on employee outcomes, such as commitment, motivation, performance which improves talent retention by reducing employees intention to leave (Carrasquer \& Martin, 2005; Hughes \& Bozionelos, 2007; Nelson et al., 1990; Scandura \& Lankau, 1997). These debates lead to the following hypothesis:

H1: There is a significant relationship between flexibility in working hours and job performance

Supportive supervision concept explores the issues of HRM practices which support WLB practices in the context of the healthcare industry in Malaysia. The fundamental goal of various enhancements in HRM policies is to attract and retain healthcare professionals in East Malaysia states, Sabah and Sarawak. Supportive HRM practices can be seen through an active job promotions and career advancement and by awarding excellent service awards (Yazid, 2010). In the doctor profession, the option for locum practice allows them to earn an extra income in the private healthcare sector while still working in the public healthcare sector (Dahlui \& Aziz, 2012). Since the healthcare industry is the Malaysian nation's key economic area, it is critical for both, federal and state health departments to continuously expand an effective and strategic HRM policies and practices. This supportive supervision is hypothesised to have a significant influence on employee job performance and satisfaction. These arguments lead to the following hypothesis:

H2: There is a significant relationship between supportive supervision and job performance

Haider et al. (2017) studied the influence of psychological well-being and satisfaction in the relationship between WLB and employee job performance. Their study suggested that psychological well-being mediates the relationship between WLB and job performance. They proposed that WLB practices will improve employee job performance by strengthening their psychological well-being. In addition, Mendis and Weerakkody (2017) also conducted a similar research concept. Their study revealed that job satisfaction significantly mediates the relationship between WLB and employee performance. These findings lead to formulate these mediation hypotheses: 
H3: Job satisfaction significantly mediates the effect of flexibility in working hours and job performance

H4: Job satisfaction significantly mediates the effect of supportive supervision and job performance

The conceptual framework for this study is developed from the above literature review. Figure 1.0 presents the relations between WLB practices (e.g. flexibility in working hours and supportive supervision), job performance and satisfaction.

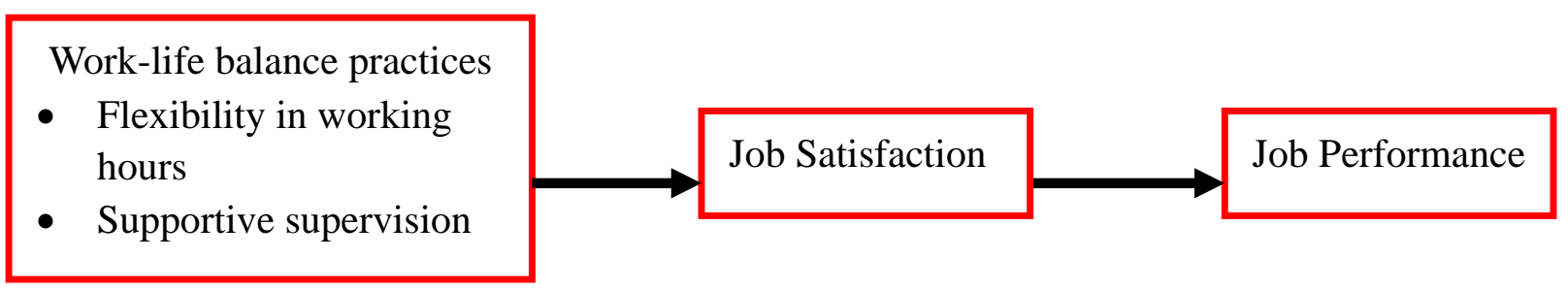

Figure 1.0. Conceptual framework: The relations between WLB practices, job performance and job satisfaction

\section{Research Methodology}

The aim of this study was to examine the relationship between WLB practices on employee job performance as well as the mediating influence of job satisfaction in the relationships among doctors and nurses in East Malaysia states.

This research employed a quantitative method whereby survey questionnaire was used for data collection. The questionnaire was designed with five major sections, Part A: Demographic, Part B: WLB, Flexibility in working hours (4 items), Part C: WLB, Supportive supervision (5 items), Part C: Job performance (9 items) and Part D: Job satisfaction (7 items). The questionnaire survey was developed based on adaptation from past researches by several scholars, whereby reliability and validity were tested. However, in this study, validity and reliability of the questionnaire were conducted as well. Expert analysis was conducted with three senior doctors, two senior nurses and one senior officer from the state health department.

Pilot test was conducted to measure the reliability for each variables of the study. This test showed that the Cronbach's alpha exceeded the threshold of 0.7 suggested by Sekaran and Bougie (2016), as follows: WLB, Flexibility in working hours (0.757), Part C: WLB, Supportive supervision (0.856), Part C: Job performance (0.938) and Part D: Job satisfaction (0.913).

The scope of the study was doctors and nurses in Sabah and Sarawak, East Malaysia region by adopting a random stratified sampling. Stratification was done based on hospitals, then, the survey questionnaires were distributed randomly in the hospital wards. According to Leedy and Ormrod (2005), 66 participants are needed as a minimum requirement. However, 610 surveys were distributed, and 491 surveys were used for data analysis using SPSS version 22.0 ( $80.5 \%$ response rates). 


\section{Data Analysis}

This study used SPSS version 22.0 for data analysis. Principal component analyses were used to examine the structure of the measures. The mediation hypotheses were tested using Barron and Kenny's (1986) procedure.

The data of this study are self-reported, from a single source and were obtained using a single method of a 7-point Likert scale (Allen \& Seaman, 2017). Harman's single factor analysis was implemented to analyse the common method variance (CMV) (Podsakoff et al., 2003). The underlying assumption of this technique is that, if a substantial amount of CMV is present, either (a) a single factor will emerge from the factor analysis or (b) one general factor will account for the majority of the covariance among the measures (Podsakoff et al., 2003). A principal component analysis was conducted on all the items and it revealed that the first component explains $38.3 \%$ of the total variance in the items, below the threshold value of $50 \%$ (Podsakoff \& Organ, 1986) which indicated there are no CMV problems.

Table 1. Pearson correlation analysis and Cronbach alphas

\begin{tabular}{|l|c|c|c|c|c|c|}
\hline & 1 & 2 & 3 & 4 & 5 & 6 \\
\hline 1. Gender & 1 & & & & & \\
\hline 2. Marital status & $0.136^{* *}$ & 1 & & & & \\
\hline $\begin{array}{l}\text { 3. WLB: Flexibility in } \\
\text { working hours }\end{array}$ & -0.012 & $-0.178^{* *}$ & $\mathbf{0 . 7 5 7}$ & & & \\
\hline $\begin{array}{l}\text { 4. WLB: Supportive } \\
\text { supervision }\end{array}$ & -.0 .003 & -0.063 & $0.533^{* *}$ & $\mathbf{0 . 8 5 6}$ & & \\
\hline 5. Job satisfaction & $-0.115^{*}$ & $-0.173^{* *}$ & $0.395^{* *}$ & $0.578^{* *}$ & $\mathbf{0 . 9 1 3}$ & \\
\hline 6. Job performance & -0.021 & $-0.141^{* *}$ & $0.344^{* *}$ & $0.473^{* *}$ & $0.490^{* *}$ & $\mathbf{0 . 9 3 8}$ \\
\hline
\end{tabular}

Gender: 1 = female, 2 = male; Marital status: $1=$ married, $2=$ single, $3=$ divorced

$* \mathrm{p}<0.05, * * \mathrm{p}<0.01, * * * \mathrm{p}<0.001$; Cronbach alphas are presented on the diagonal in bold.

Table 1.0 shows the results of Pearson correlation analysis. The correlations coefficients for all relationships between variables were less than 0.90, indicating that data were not affected by serious collinearity problems (Hair et al., 1998). In addition, Cronbach alphas for each variable exceeded 0.7 as suggested by Sekaran and Bougie (2016).

As shown in table 1.0, WLB: Flexibility in working hours has a significant positive correlation with job performance $(\mathrm{r}=0.344, \mathrm{p}<0.01)$, thereby $\mathrm{H} 1$ is supported. In addition, WLB: supportive supervision also has a significant positive correlation with job performance $(\mathrm{r}=0.473, \mathrm{p}<0.01$, therefore $\mathrm{H} 2$ is supported.

Hypothesis 3 and 4 were tested using the procedure proposed by Baron and Kenny (1986), "whereby mediation effects can be claimed if: (i) the independent variable significantly predicts the independent variable; (ii) the independent variable significantly predicts the mediating variable; (iii) when the dependent variable is regressed simultaneously on the independent variable and the mediator, the mediator significantly predicts the dependent variable is less than that obtained in Condition 1. If the independent variable has a significant 
effect in Condition 3, then there is partial mediation. If the independent variable has a non-significant effect in Condition 3, then there is full mediation. According to Baron and Kenny (1986) only condition 2 and condition 3 are needed to demonstrate mediation effects" (Bartram et al., 2012).

The result from the analyses that were conducted to test hypothesis 3 are as follows: (i) WLB, flexibility in working hours significantly predicts job performance $(b=-0.141, p<0.001)$, hence Condition 1 is met; (ii) WLB, flexibility in working hours significantly predicts job satisfaction ( $b=-0.173, p<0.01)$, hence Condition 2 is met; and (iii) job satisfaction was regressed on WLB, flexibility in working hours $(b=0.313, p<0.001)$, hence Condition 3 is met. For hypothesis 4, the analyses are as follows: (i) WLB, supportive supervision significantly predicts job performance $(b=0.344, p<0.01)$, hence Condition 1 is met; (ii) WLB, supportive supervision significantly predicts job satisfaction $(0.395, \mathrm{p}<0.01)$, hence Condition 2 is met: and (iii) job satisfaction was regressed on WLB, supportive supervision $(b=0.313, p<0.001)$, hence Condition 3 is met. Hypotheses 3 and 4 therefore supported as job satisfaction fully mediates the relationship between WLB practices (i.e. flexibility in working hours and supportive supervision) and job performance. The testing of mediating effect of job satisfaction is shown in Table 2.0 below.

Table 2. Testing mediating effect of job satisfaction using Baron and Kenny (1986)

\begin{tabular}{|l|l|l|}
\hline \multirow{2}{*}{ Variables } & \multicolumn{2}{|l|}{} \\
\cline { 2 - 3 } & Step 1 & Step 2 \\
\hline WLB (Flexibility in working hours) & $0.129 * *$ & $0.090^{*}$ \\
\hline WLB (Supportive supervision) & $0.405^{* * *}$ & $0.245^{* * *}$ \\
\hline Job Satisfaction & \multicolumn{2}{|l}{} \\
\hline \multicolumn{2}{|l|}{} & $0.313^{* * *}$ \\
\hline R Square & $0.236^{* * *}$ & $0.300^{* * *}$ \\
\hline Adjusted R Square & $0.233^{* * *}$ & $0.293^{* * *}$ \\
\hline R Square Change & $0.236^{* * *}$ & $0.064 * * *$ \\
\hline
\end{tabular}

Dependent variable: Job performance, $\mathrm{N}=491,{ }^{*} \mathrm{p}<0.05, * * \mathrm{p}<0.01, * * * \mathrm{p}<0.001$

\section{Discussion and Conclusion}

All variables of this study were reliable and valid. In addition, the results also indicated that there was a direct and significant relationship between all variables. First, flexibility in working hours had a direct and significant relationship with employee job performance. This finding is supported by earlier studies by Cegarra-Leiva et al. (2012) andMorganson et al. (2010). Furthermore, supportive supervision had a direct and significant relationship with employee job performance which is consistent with Rashid et al. (2011) and Al-Dubai et al. (2013).

The mediating effect of job satisfaction in the relationship was tested using the procedure proposed by Baron and Kenny (1986). By following the three conditions, it was found that job satisfaction had a mediation and significance relationship with WLB practices (i.e. flexibility in working hours and supportive supervision) and employee job performance. 
These findings support previous studies by Mendis and Meerakkody (2017) and Haider et al. (2017) which revealed that the better WLB practices will improve employee job performance and satisfaction. The mediation analysis also demonstrated that, in terms of explanatory power, the inclusion of job satisfaction in step 2 explained $30.0 \%$ of the variance in the dependent variable (job performance).

Findings of this study revealed that WLB practices are crucial in determining employee job performance and satisfaction. In a high-intensity work environment, the practice of flexible working arrangement and supportive supervision is crucial to improve employee attraction, retention and motivation. As elsewhere, in the East Malaysian healthcare industry, employees are required to work on fixed schedules and in shifts, which could lead to a higher work-life conflicts. This conflict was an individuals' difficulties in balancing the demands from their career, personal and family needs, which supports the previous studies by Japanese Nursing Association (2007) and Tanaka et al. (2011). The result of this study also supports the notion of the spillover effect theory (Westman, 2002; Googins, 1991). Employees perceived that the employer-oriented flexible work schedule and supportive supervisors could lessen the work-family spillovers (Garcia Cabrera et al., 2018; Wu et al., 2012; Pedersen et al., 2008; Lott, 2018; Ruppanner \& Pixley, 2012). An adequate balance between work-family and personal life will then improves their job performance and job satisfaction.

Furthermore, a formal WLB policy could mitigate this issue but it could be very costly for most organisation (Haider et al., 2017). But, a flexible working arrangement can be established because the Malaysian working culture appreciates group cooperation and harmony, dependence besides empathetic collegiate relations (Abdullah, 1996; Hassan et al., 2010; Keshavarz \& Baharudin, 2009). The concept of supportive supervision also could be observed through the East Malaysia high-power distance culture (McShane et al., 2015), in which employees have a high respect for their superiors by being dependent on their decisions and advices. They also recognised the medical knowledge, competencies and skills of their supervisors, high job integrity and cognitive and practical intelligence (McShane et al., 2015). Thus, their supervisors and senior medical practitioners can play a major role in forming an organisation that promotes WLB with less work-life conflict, which eventually enhances their job performance and satisfaction.

In regard to the practical implications of this study, a significant fundamental reform on the WLB policy at the federal Ministry of health and state health department is needed to promote a positive WLB among medical staffs. In developing this policy, critical employment aspects such as parental and marital status, job position and demand, the number of employees' in a department and the ratio of medical professional per population head in each state. In addition, a WLB policy tailored based on individual needs and requirements besides accommodates a wide range of employees and job positions will help to reduce work-life and family conflict, improve individual motivation which ultimately increases employee attraction and retention, especially in the public sector. Besides, a total commitment from the organisation and management is crucial to ensuring this policy could be effectively implemented and sustained. They must recognized the importance and influence of WLB to employee job performance, sattisfaction and well-being as well as 
willing to invest their time and effort in developing a culture of support with an efficient WLB policy. Thus, the study has successfully integrated the concept of WLB practices, employee job performance and satisfaction among doctors and nurses in the East Malaysia context. The research objectives were met with all hypotheses being supported.

\section{References}

Abdullah, A. (1996). Going global: Cultural dimensions in Malaysian management, Malaysian Institute of Management, Kuala Lumpur.

Al-Dubai, S. A. R, Ganasegeran, K., Perianayagam, W., \& Rampal, K. G. (2013). Emotional burnout, perceived sources of job stress, professional fulfillment, and engagement among medical residents in Malaysia, The Scientific World Journal, 2013. https://doi.org/10.1155/2013/137620

Allen, I. E., \& Seaman, C. A. (2007). Likert scales and data analyses, Quality progress, 40(7), 64.

Allen, T. A., Herst, D. E. L., Bruck, C. S., \& Sutton, M. (2000). Consequences associated with Allianz. (2013). Healthcare in Malaysia, Allianz Worldwide Care, $\langle$ www.allianzworldwidecare.com/healthcare-in-malaysia $\rangle$.

Augustin, R. (2017). No oversupply, high demand for Malaysian nurses, Free Malaysia Today, 7 May 2017.

Babin, B. J., \& Boles, J. S. (1998). Employee behavior in a service environment: A model and test of potential differences between men and women, Journal of Marketing, 62(2), 77-91. https://doi.org/10.1177/002224299806200206

Barron, R., \& Kenny, D. (1986). The moderator-mediator variable distinction in social psychological research: conceptual, strategic and statistical consideration, Journal of $\begin{array}{lllll}\text { Personality and Social Pschology, } & 51, & 1173-1182 .\end{array}$ https://doi.org/10.1037//0022-3514.51.6.1173

Bartram, T., Casimir, G., Djurkovic, N., Leggat, S. G., \& Stanton, P. (2012). Do perceived high performance work systems influence the relationship between emotional labour, burnout and intention to leave? A study of Australian nurses, Journal of Advanced Nursing, 68(7), 1567-1578. https://doi.org/10.1111/j.1365-2648.2012.05968.x

BERNAMA. (2008). Jururawat Masih Kurang, BERNAMA, 01 June 2008.

Blum, M. L., \& Naylor, J. C. (1968). Industrial psychology: Its theoretical and social foundations, Harper \& Row New York.

Carrasquer, P., \& Martin, A. (2005). La politica de conciliacion de la vida laboral y familiar en la negociacion colectiva. Un aspecto de la estrategia europea de empleo, Cuadernos de Relaciones Laborales, 23(1), 131-50. 
Cegarra-Leiva, D., Sanchez-Vidal, M. E., \& Cegarra-Navarro, J. G. (2012). Work life balance and the retention of managers in Spanish SMEs, The International Journal of Human Resource Management, 23(1), 91-108. https://doi.org/10.1080/09585192.2011.610955

Cooper, C. L., Rout, U., \& Faragher, B. (1989). Mental health, job satisfaction and job stress among general practitioners, British Medical Journal, 298, 366-70. https://doi.org/10.1136/bmj.298.6670.366

Dahlui, M., \& Aziz, N. A. (2012). Developing health service hub in ASEAN and Asia Region country report on Healthcare Service Industry in Malaysia in Tullao, TS and HH Lim (eds.), Research Project Report 2011-1, Jakarta.

Frone, M. R., \& Russell, M. (1997), Relation of work-family conflict to health outcomes: A four-year longitudinal study of employed parents, Journal of Occupational and Organizational Psychology, 70, 325-35. https://doi.org/10.1111/j.2044-8325.1997.tb00652.x

García-Cabrera, A. M., Lucia-Casademunt, A. M., Cuéllar-Molina, D., \& Padilla-Angulo, L. (2018). Negative work-family/family-work spillover and well-being across Europe in the hospitality industry: The role of perceived supervisor support. Tourism management perspectives, 26, 39-48. https://doi.org/10.1016/j.tmp.2018.01.006

Googins, B. K. (1991). Work/family conflicts. New York, NY: Auburn House.

Greenhaus, J. H., Collins, K. M., \& Shaw, J. D. (2003). The relation between work-family balance and quality of life, Journal of Vocational Behavior, 63, 510-31. https://doi.org/10.1016/S0001-8791(02)00042-8

Grzywacz, J. G., \& Carlson, D. S. (2007). Conceptualizing work-family balance: Implications for practice and research. Advances in developing human resources, 9(4), 455-471. https://doi.org/10.1177/1523422307305487

Haar, J. M. (2013). Testing a new measure of work-life balance: A study of parent and non-parent employees from New Zealand, The International Journal of Human Resource Management, 24(17), 3305-24. https://doi.org/10.1080/09585192.2013.775175

Haider, S., Jabeen, S., \& Ahmad, J. (2017). Moderated mediation between work life balance and employee job performance: The role of psychological wellbeing and satisfaction with co-workers. Revista de Psicologia del Trabajo y de las Organizaciones, 34(1), 1-24. https://doi.org/10.5093/jwop2018a4

Hair, J. F., Anderson, R. E., Tatham, R. L., \& William, C. (1998). Black (1998), Multivariate data analysis, Upper Saddle River, NJ: Prentice Hall.

Hassan, Z., Dollard, M. F., \& Winefield, A. H. (2010). Work-family conflict in East vs Western countries, Cross Cultural Management: An International Journal, 17(1), 30-49. https://doi.org/10.1108/13527601011016899 
Hughes, J., \& Bozionelos, N. (2007). Work life balance as source of job dissatisfaction and withdrawal attitudes. An exploratory study on the views of male workers, Personnel Review, 36(1), 145-54. https://doi.org/10.1108/00483480710716768

Jabatan Perdana Menteri. (2012). Economic Transformation Programme: Annual Report 2012, Malaysia.

Joshi, S., Leichne, J., Melanson, K., Pruna, C., Sager, N., Story, C. J., \& Williams, K. (2002). Work life balance: A case of social responsibility or competitive advantage?, Georgia Institute of Technology, Georgia, US.

Keelan, R. (2015). A Māori perspective of well-being. He Kupu Vol, 4.

Keshavarz, S., \& Baharudin, R. (2009). Parenting style in a collectivist culture of Malaysia, European Journal of Social Sciences, 10(1), 66-73.

Kossek, E. E., \& Ozeki, C. (1998). Work-family conflict, policies and the job-life satisfaction relationship: A review and directions for organizational behaviour-human resources research, Journal of Applied Psychology, 83, 139-49. https://doi.org/10.1037/0021-9010.83.2.139

Leedy, P. D., \& Ormrod, J. E. (2005). Practical research: Planning and design, Pearson.

Lott, Y. (2018). Does flexibility help employees switch off from work? Flexible working-time arrangements and cognitive work-to-home spillover for women and men in Germany. Social Indicators Research, 1-24. https://doi.org/10.1007/s11205-018-2031-z

Madsen, S. R. (2006). Work and family conflict: Can home-based teleworking make a difference?, International Journal of Organization Theory and Behavior, 9(3), 307-50. https://doi.org/10.1108/IJOTB-09-03-2006-B002

Maslach, C., Schaufeli, W. B., \& Leiter, M. P. (2001). Job burnout. Annual review of psychology, 52(1), 397-422. https://doi.org/10.1146/annurev.psych.52.1.397

McShane, S., Olekalns, M., Newman, A., \& Travaglione, T. (2015). Organisational Behaviour $5 e$; Emerging Knowledge. Global Insights, McGraw-Hill Education, Australia.

Mendis, M. D. V. S., \& Weerakkody, W. A. S. (2017). The impact of work life balance on employee performance with reference to telecommunication industry in Sri Lanka: A mediation mode. Kelaniya Journal of Human Resource Management, 12(1), 72-100. https://doi.org/10.4038/kjhrm.v12i1.42

Moen, P., Kelly, E., \& Huang, R. (2008). Fit inside the work-family black box: An ecology of life course, cycles of control reframing, Journal of Occupational and Organizational Psychology, 81, 411-33. https://doi.org/10.1348/096317908X315495

Mohamed, W. N., \& Mohamad, M. (2012). Measuring the quality of nursing work life in public hospitals, paper presented to International Conference on Management, Langkawi Kedah, Malaysia. Retrieved from http://www.internationalconference.com. Date accessed: 20 January 
2015my/proceeding/2nd_icm2012_proceeding/076_187_2ndICM2012_Proceeding_PG1018 _1028. pdf

Morganson, V. J., Major, D. A., Oborn, K. L., Verive, J. M., \& Heelan, M. P. (2010). Comparing telework locations and traditional work arrangements: Differences in work-life balance support, job satisfaction and inclusion, Journal of Managerial Psychology, 25(6), 578-95. https://doi.org/10.1108/02683941011056941

MyMetro. (2014). Jururawat kita jadi “rebutan”, Harian Metro, 22/09/2014.

Nelson, D. L., Quick, J. C., Hitt, M. A., \& Moesel, D. (1990) Politics, lack of career progress and work/ home conflict: Stress and strain for working women, Sex Roles, 23(3/4), 169-85. https://doi.org/10.1007/BF00289864

Netemeyer, R. G., Brashear-Alejandro, T., \& Boles, J. S. (2004). A cross-national model of job-related outcomes of work role and family role variables: A retail sales context, Journal of the Academy of Marketing Science, 32(1), 49-60. https://doi.org/10.1177/0092070303259128

Noor, K. M. (2011). Work-Life Balance and Intention to Leave among Academics in Malaysian Public Higher Education Institutions, International Journal of Business and Social Science, 2 (11), 240-8.

Pedersen, D. E., Minnotte, K. L., Kiger, G., \& Mannon, S. E. (2009). Workplace policy and environment, family role quality, and positive family-to-work spillover. Journal of Family and Economic Issues, 30(1), 80. https://doi.org/10.1007/s10834-008-9140-9

Podsakoff, P. M., \& Organ, D. W. (1986). Self-reports in organizational research: Problems and prospects, Journal of Management, 12(4), 531-44. https://doi.org/10.1177/014920638601200408

Podsakoff, P. M., MacKenzie, S. B., Lee, J. Y., \& Podsakoff, N. P. (2003). Common method biases in behavioral research: a critical review of the literature and recommended remedies, Journal of Applied Psychology, 88(5), 879. https://doi.org/10.1037/0021-9010.88.5.879

Poulose, S., \& Sudarshan, N. (2014). Work Life Balance: A conceptual Review, International Journal of Advances in Management and Economics, 3(2), 1-17.

Rashid, W. E. W., Nordin, M. S., Omar, A., \& Ismail, I. (2011). Evaluating social support, work-family enrichment and life satisfaction among nurses in Malaysia. Paper presented in the 2011 International conference on Management and Service Science. https://doi.org/10.7763/IJSSH.2011.V1.26

Razak, A. Z. A. A., Yunus, N. K. Y., \& Nasarudin, A. M. (2011). The impact of work overload and job involvement on work-family conflict among Malaysian doctors, Labuan e-Journal of Muamalat and Society, 5, 1-10.

Razak, A. Z. A. A., Yunus, N. K. Y., \& Nasarudin, A. M. (2011). The impact of work overload and job involvement on work-family conflict among Malaysian doctors, Labuan e-Journal of Muamalat and Society, 5, 1-10. 
Ruppanner, L., \& Pixley, J. E. (2012). Work-to-family and family-to-work spillover: The implications of childcare policy and maximum work-hour legislation. Journal of Family and Economic Issues, 33(3), 283-297. https://doi.org/10.1007/s10834-012-9303-6

Scandura, T. A., \& Lankau, M. J. (1997). Relationships of gender, family responsibility and flexible work hours to organizational commitment and job satisfaction, Journal of Organizational Behavior, 18, 377-91. https://doi.org/10.1002/(SICI)1099-1379(199707)18:4<377::AID-JOB807>3.0.CO;2-1

Sekaran, U., \& Bougie, R. (2003). Research methods for business: A skill building approach, John Wiley and Sons Inc., New York.

Sekaran, U., \& Bougie, R. (2003). Research methods for business: A skill building approach, John Wiley and Sons Inc., New York.

Sibbald, B., Enzer, I., Cooper, C., Rout, U., \& Sutherland, V. (2000). GP job satisfaction in 1987, 1990 and 1998: Lesson for the future? Family Practice, 17(5), 364-71. https://doi.org/10.1093/fampra/17.5.364

Smucker, M. K., Whisenant, W. A., \& Pedersen, P. M. (2003). An investigation of job satisfaction and female sports journalists. Sex roles, 49(7-8), 401-407. https://doi.org/10.1023/A:1025120406343

Wagner, A. J. (1994). Participation's effects on performance and satisfaction: A reconsideration of research evidence, Academy of Management Review, 19, 312-330. https://doi.org/10.5465/amr.1994.9410210753

Westman, M. (2002). Crossover of stress and strain in the family and in the workplace. In P.L. work-to-family conflict: A review and agenda for future research, Journal of Occupational Health Psychology, 5(2), 278-308. https://doi.org/10.1016/S1479-3555(02)02004-8

Wu, L. Z., Kwong, K. H., Liu, J., \& Resick, C. J. (2012). Work-to-family spillover effects of abusive supervision. Journal of Managerial Psychology, 27(7), 714-731. https://doi.org/10.1108/02683941211259539

Yazid, Z. (2010). Gaji Lumayan Jadi Tarikan, Utusan Online

Zapf, D., Seifert, C., Schmutte, B., Mertini, H., \& Holz, M. (2001). Emotion work and job stressors and their effects on burnout. Psychology \& Health, 16(5), 527-545. https://doi.org/10.1080/08870440108405525

\section{Copyright Disclaimer}

Copyright for this article is retained by the author(s), with first publication rights granted to the journal.

This is an open-access article distributed under the terms and conditions of the Creative Commons Attribution license (http://creativecommons.org/licenses/by/4.0/). 